\section{Oral anatomy in the sixteenth century: Juan Valverde de Amusco}

\author{
A. López-Valverde, ${ }^{* 1}$ R. Gómez de Diego ${ }^{1}$ and J. De Vicente ${ }^{1}$
}

IN BRIEF
- Discusses Juan Valverde de Amusco's The
history of the composition of the human
body, one of the most read anatomic-
related documents in the sixteenth
century.
- Stresses its importance as a historical
document, describing with precision
the anatomy of the facial bones and
teeth from their morphology to their
vascularisation and innervation.

\begin{abstract}
In 1554 Juan Valverde de Amusco, a Spanish anatomist, wrote the History of the composition of the human body, a complete anatomical treatise that took as its model the Vesalius school of thought (La fábrica of Vesalius). Considered one of the most complete anatomical treatises of the Renaissance and one of the most widely read books of the sixteenth century, it was translated into four languages in its day. The first chapter, devoted to bones, provides a meticulously detailed analysis of the bones of the facial structures and of the teeth, their supporting structures, vascularisation and innervation. Juan Valverde de Amusco even describes techniques for reducing mandibular luxations. Even with the imprecise observations typical of the time the treatise must be considered an exceptional document.
\end{abstract}

\section{INTRODUCTION}

With a view to better understanding Galen medicine, the end of the thirteenth century saw the beginnings of regular dissection of cadavers in Bologna. Later, this was propagated to Padua, Montpellier and Lérida.

At the dawn of the sixteenth century, the Italian School produced anatomists of great renown, such as Gabrielle Zerbi, Berengario da Carpi and Alessandro Achillini, who introduced comments and descriptions based on their own experience. In this sense, it would also be necessary to mention the Spaniard Andrés Laguna, who in his Anatomica methodus (1535), added personal observations based on cadaver dissection. All of these men are considered to have been the precursors to Vesalius. ${ }^{1}$

In 1542 Vesalius wrote his famous treatise, dedicated to Emperor Charles V and his son Phillip II.

His followers corrected and broadened the scope of the descriptions of the human body given by Vesalius and, additionally, began comparative, embryological and structural studies.

${ }^{1}$ Associate Professor, School of Dentistry, Faculty of Medicine, Department of Surgery, University of Salamanca, 37007, Spain

*Correspondence to: Dr Antonio López-Valverde Email: anlopezvalverde@gmail.com; Tel: 0034923294500 - ext 1996

\section{Refereed Paper}

Accepted 4 April 2013

DOI: $10.1038 /$ sj.bdj.2013.735

${ }^{\circledR}$ British Dental Journal 2013; 215: 141-143

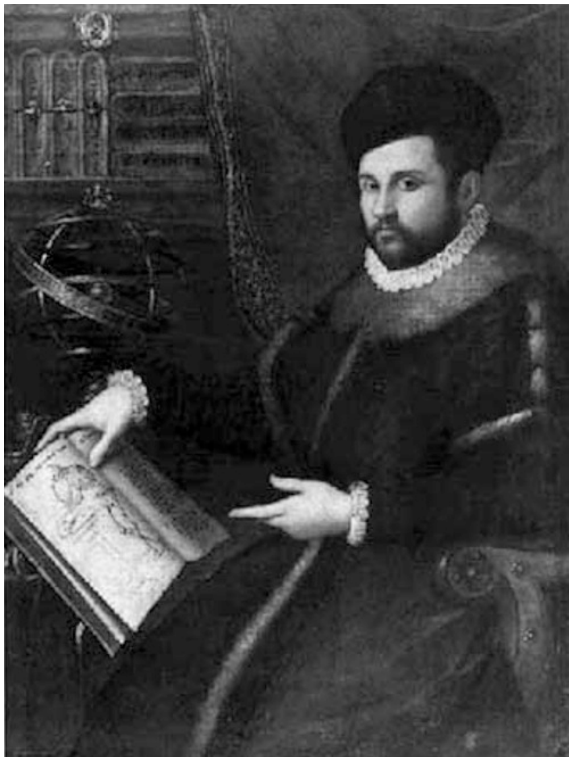

Fig. 1 Valverde de Amusco. Portrait. With permission Banco de imágenes, Real Academia Nacional de Medicina, España

Realdo Combo followed Vesalius in the Chair of Anatomy of Padua. Giulio Cesare Aranzio and Constanzo Varolio were professors at Bologna and Giovanni Filippo Ingrassia in Naples. One of Realdo Colombo's closest disciples was Valverde de Amusco (Fig. 1).

Of Jewish origin, Valverde was born in Amusco (Palencia, Spain) around 1525. He followed the general studies of philosophy and the humanities at the University of Valladolid (Spain), a city that in those times was the capital of the Kingdom of Spain. Around 1542, possibly owing to the

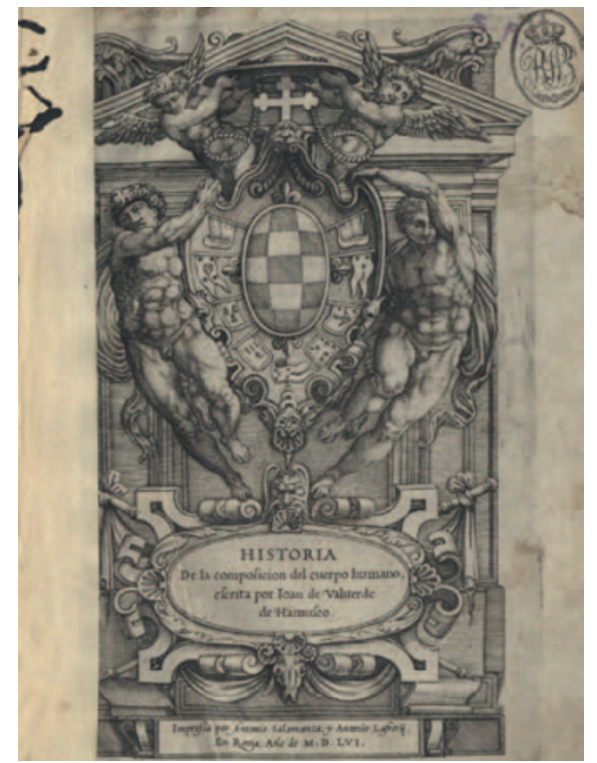

Fig. 2 Bookcover 'Historia de la Composición del Cuerpo Humano'. With permission Biblioteca Nacional Digital de España

prevailing anti-Semitism of the period, he travelled to Italy to study anatomy under the guidance of Realdo Colombo in Padua, where he remained from 1545 to 1548 . He then went to Rome, where he lived and worked until 1589, possibly the year of his death. ${ }^{3,4}$ His in-depth knowledge of anatomy is reflected in his book entitled A history of the composition of the human body $y^{5}$ devoted to his benefactor Cardinal Juan Álvarez de Toledo; indeed, he was the Cardinal's personal physician. The work is considered to be the most widely read text in Europe in the sixteenth century. 
His work was published in Rome in 1556 by Antonio de Salamanca and Antoine Lefrery (Fig. 2).

This anatomical treatise comprises seven chapters or 'books' where Valverde studies the different parts of the human body, from the bones in the 'Libro primero' to the sense organs in the 'Libro séptimo'.

In his dedication he says that he had written the work owing to the lack of physicians sufficiently well-versed in anatomy in Spain, due to the country's prohibition against the dissection of human cadavers. This, however, is not strictly true, since in 1550 Emperor Charles V discussed the legality of dissections with the University of Salamanca, which gave its approval.

He also tells us that another reason for his treatise was the confusing presentation by Vesalius in his own work.

The anatomical illustrations ('tabvlas') - 42 of them in all - that appear in the book are one of its most outstanding features. They were all inspired by classic medical treatises, intermingling science and art, and although the tabvlas have been considered by some authors as mere copies of Vesalius' plates, Valverde said that he wished to 'improve them and correct their errors'. The person charged with the drawings was the Spanish painter Gaspar Becerra, a disciple of Miguel Angelo Buonarroti. ${ }^{8}$

\section{BOOK I. OF THE BONES (FIG. 3)}

\section{Chapter IV. Of the superior bones of the face (Huessos de la quixada de arriba)}

Valverde defines the superior maxilla as "the whole of the face between the eyebrows at the top and the mouth at the bottom'; with this anatomical terrain encompassing 12 bones, 6 on each side, with all 12 being classified as "thin and hard'.

The first bone (malar) 'occupies a space ranging from the end of the brow to close to the nose and the greater part of the cheek'

The second (lachrymal bone), 'which is scale-like and almost round, is situated at the front part of the medial wall of the orbit, next to the lachrymal gland', which Valverde defines as 'the smallest bone in the superior maxilla' and says that 'it is infrequently found intact in skulls from cemeteries'
The third bone (the sphenoid) is located behind the second one. It is square and he defines it as 'as thin as it is translucent'.

The fourth (the maxillary bone), which is the largest of the whole of the superior maxilla, "joins up with that on the other side and is where all the upper teeth and molars are housed'. He describes its spongy aspect as 'a structure similar to a honey-comb'. Of all the holes (orifices) in this bone, only one "which is seen in the cheek' (the infraorbital orifice) is classified as being important.

The fifth (the nasal bone) "joins with the one on the other side and forms the anterior part of the nose'. He classifies them as 'hard, thin and broad'.

The sixth (the palatine bone), together with that of the other side, "conforms the posterior part of the palate and the base of the nose and it is broad, thin and strong, and the sides of the posterior parts of each of them rest on the posterior exits of the cuneal bone'.

\section{Chapter VI. Of the inferior bones of the face (Huessos de la quixada de $a b a x o$ )}

Valverde defines the inferior maxillary as 'the set of the chin and the mandibles' (ascending and descending branches) that encompasses the lower teeth and the jaw, composed of two halves joined at the midline by a line which, in children, is softer than the bone. He refers to as the 'Simphisis' (chin symphisis). Regarding this line he states that it features the insertions of some muscles that move the lower lip.

With respect to the shape of the mandible, he classifies it as 'thick in the area of the chin, then thinning out towards the body and ascending branch of the mandible'. These mandibles ascend towards the ears (ascending branch) and then split into two horn-like shapes. 'The anterior part (the coronoid apophysis) narrows at the end and the temple muscles are joined to that horn' (the temporalis muscle). 'The posterior part is wider and fits in a corner close to the ear' (the glenoid cavity of the temporalis). 'This broad zone of the posterior horn is rounded and together with its counterpart on the other side allows the mandible to move'. He describes that it may become luxated with too strong a yawn and the technique for reducing the luxation is as follows: "placing the thumb

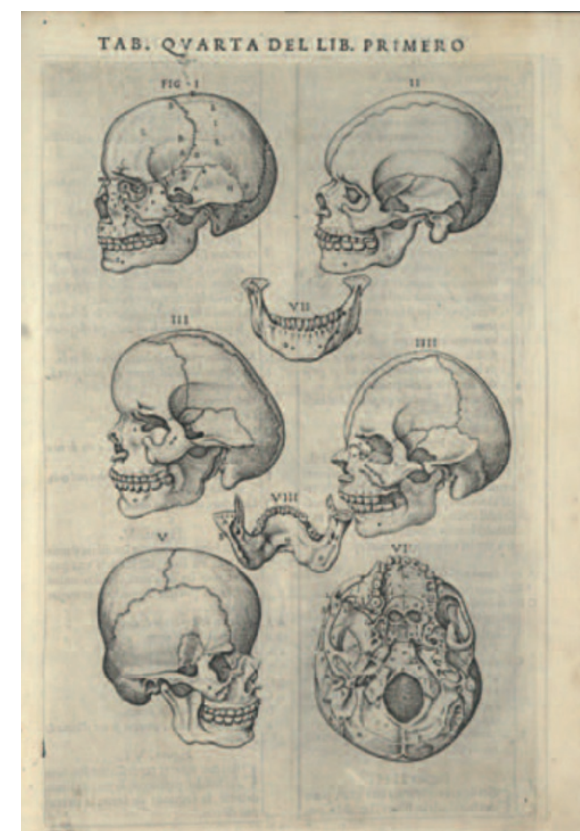

Fig. 3 Illustration of teeth and craniofacial structures ('TABVLA IIII'). With permission Biblioteca Nacional Digital de España

under the tip of the ear, slightly forwards, and pushing strongly inwards, first on one side then on the other'.

He describes two orifices on each hemimandible, one on the interior part (the mandibular orifice) and the other on the exterior part (the mental orifice), communicating with each other (in the manner of a tunnel). The outer part is 'situated between the root of the canine and the teeth following it'.

'Through each small hole enters a branch of the third pair of nerves, which courses towards the roots of the teeth, accompanied by a vein and an artery, and it exits through the exterior hole, splitting into different branches that are scattered over the lower lip'.

As anatomical accidents, he describes 'bone roughnesses' on the internal face of the chin (apophysis geni), "into which the muscles that move the mandible are inserted'.

\section{Chapter VII. Of the teeth}

Valverde classifies these as 'bones different from other bones', stating that they 'grow throughout a person's lifespan, as can be seen in those who do not have opposing teeth' (referring to dental extrusions due to the lack of antagonist teeth).

He numbers them at 32, 16 per arch, and comments at the beginning of the chapter that children attain their definitive dentition between five and nine years of age. 
Regarding the number of molars, he comments that 'some people have four on each side or four on one side and five on the other. These variations are caused by the socalled cordal molars (wisdom teeth) which grow after men's beards have appeared and sometimes do not grow on both sides'

Valverde defines the four incisors with the Greek name of 'tomis' (cutters), with a single root, after which he describes the canines, one on each side, 'because they are similar to dogs' teeth' (canis in Latin). Later come the molars (molarem dentem) because we use them to grind our food. Valverde does not differentiate premolars from molars.

'The bottom teeth have two roots and sometimes three, and the upper teeth have three, occasionally four, mainly the posterior-most ones'.

'All the roots have a small hole that accommodates a vein, a nerve and an artery' (apical foramen). The dental alveoli are defined with the Latin term 'praesepiola' (referring to a manger where animals are fed in stables).

\section{DISCUSSION}

In the sixteenth century it became important to know the shape of the human organs in order to understand and explain their functions. Cadaver dissections, which were prohibited or at least censored for many centuries, were sanctioned, and in some cities they became social meetings for which quite spectacular dissecting theatres were built. Intent upon showing this reality that he observed personally in dissections, Andrés Vesalius wrote the De humane corporis fabrica libri Septem and illustrated the work with the help of his fellow Flemish countryman Jan van Kalkar, a student at the atelier of the great painter Tiziano Vecellio. The quality of $L a$ fábrica, as the work is known in colloquial terms, is such that thenceforth any anatomical description that did not include the novel and precise Vesalian viewpoint was deemed unacceptable.

Valverde took Vesalius' work and subjected it to an intelligent reworking, checking, in the dissections he performed, the knowledge and findings that Vesalius had explained in his work De humani corporis fábrica libri septem.
Valverde tried to change the Vesalian style of presentation, noting down the omissions and mistakes that he found in Vesalius' work. Authors such as Alberti cite up to 32 rectifications, the most important referring to the muscles, in particular the oculo-motor muscles, those of the face, those of the throat and those of the palm.

According to himself, Valverde's contributions came from what he had seen in the dissections of human bodies, nearly always in collaboration with Realdo Colombo. He also mentions the origins of the illustrations of his work, most of which came from Vesalius' La fábrica. In their study of these illustrations, Meyer and Wirt consider that only 15 were from Valverde himself, among them some of great scientific importance, such as four figures depicting the eye muscles and another of the ear bones, including the stirrup. ${ }^{8}$ However, the most famous are two plates of great beauty, one of which represents a muscled man and the other representing a pregnant woman with the abdominal wall and peritoneum exposed to show the occupied uterus. It included a complementary plate of a fetus joined to an umbilicus. In any case, the traditional attribution of these illustrations - in the form of copper-plate tracings and not woodcuts as in the case of Vesalius' La fábrica - to Gaspar Becerra has not been fully resolved., ${ }^{5,9}$

The accusation of plagiarism of Vesalius' work by Valverde is currently unsustainable. The expositive clarity of Valverde was one of the main reasons why his work became the anatomical treatise that attained the greatest diffusion throughout Europe in the sixteenth century, exceeding the excellence of Vesalius' own work, and of re anatomica (1559) by his maestro Realdo Colombo, a work lacking illustrations.

Either completely or in parts, Valverde's work was re-published 16 times in 4 languages in slightly more than a century; the languages were Spanish, Dutch, Italian and Latin. Today there is even a Greek adaptation dating from the start of the eighteenth century.

Vesalius' work, published in academic Latin, has been hailed as 'the most important medical book published in all time'. However, there are still many Galenic concepts, which were improved by his successors, namely Juan Valverde de Amusco, considered one of the most brilliant Hispanic scientists of all time.

Only a small part of the Vesalius' work is about teeth and Valverde mistook them as bones. Only Realdo Colombo, disciple of Vesalius and Valverde's teacher, described dental follicles in foetuses. However, in 1561 Gabrielle Falloppio described, in his book, the dental follicle and demonstrated that permanent teeth develop independently of the primary teeth.

The mandible is described morphologically with complete accuracy, from the apophysis geni to the three sections of the mandibular canal and even when referring to the dislocation of the temporomandibular joint.

The facial expression muscles are seen in several drawings. The dissection, in levels, shows chewing muscles, like the masseter, temporal, internal pterygoid, supra-hyoid and infra-hyoid. In the drawings where the mouth is opened or in those where the mandible had been removed the activity of those muscles can be observed.

Therefore, Valverde's terminology, the detail in his descriptions and his clarity of exposition, together with the comparative anatomy and therapeutic recommendations sometimes provided mean that his work is an anatomical-historical document of great interest.

1. Lain Entralgo P. Historia universal de la medicina. Vol IV. Barcelona: Salvat Editores, 1972.

2. Martín Araguz A, Bustamante Martinez C, Toledo León $D$, López Gómez M, Moreno Martínez J M. The neuroanatomy of Juan Valverde de Amusco and medicine at the time of the Spanish renaissance. Rev Neuro/ 2001; 32: 788-797.

3. Fernández Ruiz C. Biographic study on Dr. Juan Valverde, famous anatomist of the 16th century and his work. Clin Lab 1958; 66: 207-240.

4. Alberti L. La anatomía y los anatomistas españoles del Renacimiento. C.S.I.C. pp 81-130. Madrid,1948.

5. Valverde de Amusco J. Historia de la composición del cuerpo humano. Google Books.

6. Prieto Carrasco C. Dos estudios sobre la enseñanza de la medicina en la Universidad de Salamanca. Acta Salamanticensia. Historia de la universidad. Salamanca, 1986.

7. Valle-Inclán $\mathrm{C}$ del. El léxico anatómico de Bernardino Montaña de Monserrate y de Juan de Valverde. Archivos Iberoamericanos de Historia de la Medicina 1949; 1: 121-188.

8. Meyer A W, Wirt S K. The Amuscan illustrations. Bulletin of the History of Medicine 1943; 14: 667-687.

9. Boorsch W L, Strauss S. The illustrated bartsch 29 (formerly vol 15, part 2). Italian masters of the sixteenth century. New York: Abaris Books, 1982.

10. Barona Villar J L. El pensamiento biológico de Juan Valverde de Amusco. Physis 1992; 29: 375-402.

11. Friedman M D, Friedland G W. Medicine's 10 greatest discoveries. New Haven: Yale University Press, 1998 